\title{
SOME CHALDON WITCHES
}

\author{
Judith Stinton
}

There is a remarkable photograph of Annie Moxon, which was taken by Valentine Ackland in the early 1930s. She sits squarely in the darkness of her living-room in her muddy shoes, wedding photograph on the wall, china on the dresser. She is holding what looks like a notebook, and it would be agreeable to think that the book is Opus 7 (1931), the long poem by Sylvia Townsend Warner which reinvents Annie Moxon, their Chaldon neighbour, as 'Rebecca Random'.

It's an extraordinary poem, skilfully written in flowing couplets. Set in 'Love Green' it tells of Rebecca, an old woman who has the 'easiest soil' in Love Green (Warner, 2008, p.159) and is blessed with 'green thumbs'. (p.161) Her garden is extravagantly full of flowers instead of the usual workaday vegetables. On receiving the unexpected windfall of a pound note, she invests some of it in yet more flowers, in the shape of seed packets from Dorchester Woolworth's: 'the Araby, Spice Island, Walsinghame/miraculous of every village dame,/ who from its many-breasted mercies drew/ the joys of spending and of saving too'. (p.171)

Her gamble pays off, the flowers sell, and Rebecca uses the money to buy gin - gin which is to be her ruin. She dies in the churchyard, one chilly night:

She, in this winter midnight, in this place of death, fit tavern for one of mortal race, 
with her two bottles left her...

would teach this God a lesson how to drink

Like Annie Moxon, Rebecca has no faith in God. Warner and Ackland admired Annie for this. Of all the people in the village, apart from Theodore Powys and his wife Violet, they were most devoted to Annie Moxon and to Shepherd Dove. Known, like most of the older women, as 'Granny', she was believed to be a witch, one of several in Chaldon. Certainly she was a remarkable woman. Ackland particularly felt a strong affinity with her, and paid tribute in an article for the Countryman in 1949 , at a time of great crisis in her relationship with Sylvia. Perhaps she was recalling happier years.

A small, quick woman, with a light step and an agile tongue, Granny Moxon was over seventy when I first knew her, and she had lived alone for more than twenty years. Her husband had been a blacksmith, and his photograph showed a solemn, powerful man, but she told me that if he provoked her (and he was an annoying man at times, she said, being slow in the uptake and too cautious for her taste) she would pick him up and run round the kitchen table with him, and at last dump him down hard on the stone floor. This never failed to bring him to his senses.

When she told such a story she would throw back her head and laugh - a laugh exactly like a woodpecker's cry, harsh and wild. She had exceedingly brilliant blue eyes which flashed and sparkled in her head like stars on a frosty night. Her hands were small and brown and very strong. She worked in her garden like a man, but more quickly than any local man would work, and everything there flourished. I never knew her to have a bad season... 
Most evenings, winter and summer, she crossed her garden and climbed over the fence to the village inn, where she settled down to talk and tell stories and sometimes to play her accordion. She had a variety of songs, some of them very mysterious. I remember two lines from a long ballad:

'Every hair of her head it is missing/ And mourned by a daughter or son'. She could not explain them when I asked her to, but she said that she understood them perfectly well, and that she had known the song all her life.

Granny Moxon was very wise and very merciful. In this she was unlike any of the other inhabitants of the village. Her stories were merry and often bawdy, but quite innocent of any moral judgements. She was god-like in her indifference and her fearlessness, and she loved human folly with a curious, protective affection; very much as she loved the goldfinches she kept in cages in her room, running her nails across the bars of their cages to make them start and twitter, and then laughing aloud with glee, and poking little bits of sugar through the bars to comfort them.

She told me one day, when she was about seventy-five years old, that she had walked to the next village to see the doctor, and as she came back along the road, walking briskly as usual, a young soldier had followed her ... and, seeing her limber step ... had whistled to her and called out that she should wait for him. So she slowed down and waited until he was close behind, and then 'I turned meself round and showed he my wold face, and Lard! he were proper scared!' And then she threw back her head and laughed her woodpecker laugh, and said 
after a moment of pure enjoyment: 'Poor young chap, too; he thought I were a maid. "Ah," I said to en, "Wish I had a bin," I said; "I wish I had bin a maid!"

Her speech was as supple as her movements, when she was talking or telling a story in the pub, and she spoke with a pure Dorset dialect of which she was very proud. But at times her words became stately and had great grandeur, and that was when she conversed about death and the fate of man. We do not live after death, she said; there is a hole made in the ground and there we be laid in the earth, and that is the end of all. 'Never you go looking to live,' she said, 'for you ha'ant never seen no-one come back from the dead'.

When she was dying of cancer I visited her, and when I found that she knew she was dying, I asked her again what she expected of death, and she repeated what she had said before: 'Never you go looking to live - ". Holding her hard brown hand I looked down on her and she gazed back at me. I remembered the image used by Bede in our seventh century and by a Chinese sage two thousand years before Christ: "As he entered death he did not hang back. Like a bird he flew away, just as like a bird he came; that was all'.

When she had died the village was like the dead body she had talked of, laid by in a hole in the ground; for she had been the spirit, incomprehensible, irreplaceable; gone no-one knows where.

(Ackland, 1949b, pp.246-247)

After Mrs Moxon's death, Warner wrote an elegy for her.

Twenty times, I suppose, I've danced alone- 
And no one wagged a better bone

Than I, in times gone by -

But $\mathrm{Oh}$ - remembering freely, as I can,

When first I had my man

Clapped in my arms so neat and spry -

No girl so glad as I!'

'No girl so glad as I -' she said -

And like a jay's cry overhead

Her laugh shrieked across the room -

Strange that she's gone - and why? -

To dark earth, lonely tomb.

Annie Moxon also appears in an untitled poem from Whether a Dove or Seagull, in which she becomes not just the spirit of the village, but of the earth too.

So has this day's fierce dusk remembranced me;

Since, walking homeward on the volleying wind

With half my mind

Countering the gusts, and half lost and enlaced

In the wild vespers cried from the bare boughs,

I passed the house

Where under the sagging thatch dwells she whom all

Think witch, and call Grannie - though she goes light-foot as a girl

Under her three-score years and ten. There,

With wind-wisped hair

Straggling under hat rammed down and roughshod

Small foot on spade, obstinate to the blast, The ill day's last

Opponent, she worked her winter ground for spring.

(STW in Warner and Ackland, 1933. p.21) 
As the sun breaks through, Grannie - the patient digger, the prodigal grower - is crowned with glory, transformed into an exalted, almost mystical figure in Warner's eyes:

And now like a dream's survival I behold Her in that gold

Surprised, standing above her broken ground,

As though at that trump, at that summons shining and fervent, $O$ faithful servant

Enter now into the reward of thy labours, Not she, not she, but earth's very spirit

Rose to inherit

Light everlasting, the manifested coronal

of long darkness, of long-ploughed patience,

Long acquiescence

Of the nourishing breast, of the receiving lap;

Although the Be fruitful since far creation obeyed

Were now repaid

In that fierce dusk, so wild with singing and storm.

Sylvia Townsend Warner had of course written about witches before, in her second book Lolly Willowes. In that novel, after the death of her father Laura (known familiarly as Lolly) goes to live with her brother Henry and his family in London. Enduring long years of a pattern regular as wallpaper, Laura becomes restless on return from one annual holiday.

What it was exactly, she would have found hard to say. She sometimes told herself that it must be the yearly reverberation of those miserable first months in London when her 
sorrow for her father's death was still fresh. No other winter had been so cold or so long, not even the long cold winters of the war. Yet now her thoughts of Everard were mellowed and painless, and she had long ago forgiven her sorrow. Had the coming of autumn quickened in her only an experienced grief she would not have dreaded it thus, nor felt so restless and tormented.

Her disquiet had no relevance to her life. It arose out of the ground with the smell of the dead leaves; it followed her through the darkening streets; it confronted her in the look of the risen moon. 'Now! Now!' it said to her: and no more. The moon seemed to have torn the leaves from the trees that it might stare at her more imperiously. Sometimes she tried to account for her uneasiness by saying that she was growing old, and that the year's death minded her of her own. She compared herself to the ripening acorn that feels through windless autumnal days and nights the increasing pull of the earth below. That explanation was very poetic and suitable. But it did not explain what she felt. She was not wildly anxious either to live or to die; why, then, should she be rent by this anxiety?

(Warner, 1993, pp. 75-76)

Laura develops what her nearest and dearest regard as extravagant ways, culminating in the purchase in Bayswater of an enormous bunch of chrysanthemums. The shopman throws in some sprays of bay leaves, which 'smelt of woods, of dark rustling woods like the wood to whose edge she came so often in the country of her autumn imagination'. (p.86) The leaves come from near Chenies in Buckinghamshire. This is clue enough for Laura, who rushes off to buy a Chilterns guidebook and a 
detailed map. She then announces to her bewildered relations that she is going to live in the Chilterns at Great Mop.

Great Mop, of course, turns out to be a village full of witches, and Laura joins them, coming out as a witch. She has found her vocation, as she explains to her master, the Devil.

'It's like this. When I think of witches, I seem to see them all over England, all over Europe, women living and growing old, as common as blackberries, and as unregarded. I see them, wives and sisters of respectable men, chapel members, and blacksmiths, and small farmers, and Puritans. In places like Bedfordshire, the sort of country one sees from the train. You know. Well, there they are, child-rearing, house-keeping, hanging washed dish-clothes on currant bushes; and for diversion each other's silly conversation, and listening to men talking together in the way that men talk and women listen. Quite different to the way women talk, and men listen, if they listen at all. And all the time being thrust further down into dullness when the one thing all women hate is to be thought dull.

(pp.234-235)

If women know themselves to be witches, that secret brightens their lives.

'Respectable countrywomen keep their grave-clothes in a corner of the chest of drawers, hidden away, and when they want a little comfort they go and look at them, and think that once more, at any rate, they will be worth dressing with care. But the witch keeps her cloak of darkness, her dress 
embroidered with signs and planets; that's better worth looking at.

(p.237)

Warner's witches are a rural phenomenon: they are of the earth, earthy. And as it is the twentieth century, their powers have dwindled; they have become rather modest. This is true of Bessie Cornick, a huge old lady who smoked Player's, cigarettes and was described by both Warner and Ackland in their different ways. In Ackland's essay, 'The Village Witch' published in West Country Magazine (Autumn 1949), she goes under the name of 'Old Allie'.

I first came to the village when $I$ was nineteen. . . At that date (it was in the middle 1920s) my generation was deep in Hardy and T.F.Powys; they had modern pictures and the plays of Tchekhov as their background. It was the fashion to observe, rather than to judge, and we were impossible to surprise.

The old woman who wore a round knitted cap and laboured past my window every day, carrying her buckets to and from the well, was called Old Allie, and everyone knew that she was a witch. Each Sunday she rang the church bell for early service and for evensong. Each Saturday she swept out the church. Her cottage stood below the churchyard, which sloped steeply downhill, and the bottom-most gravestones nodded in at her bedroom window. The place was always damp and the farmer who owned it would not bother to keep it in repair. One day, as I was told, Old Allie paid him a formal visit of complaint, and when he turned her roughly from his door, she waddled slowly round to his cow-byre and, watched by one of the men, leaned in over 
the door and spoke a word or two. Next day his best cow was dead.

"Do you really believe that Old Allie is a witch?" I asked the farmer, foolishly.

"I don't believe it, I do knaw." And he left me to ruminate on that.

Old Allie did very little serious witchcraft, apart from this performance. She played mischievous, sometimes malicious tricks, and worked just hard enough, as it were, to keep people in awe of her; and so they gave her little presents of tobacco . . . or snuff or newly-made jam. And when she died ... all the people of the village called in at her cottage, decorously, in ones and twos, and carefully examined every cranny. Everyone saw the bottle which hung half-way up the huge chimney; it contained a charm or a spell, they thought, and perhaps it was there to keep away the devil. Opinion was divided about this, for it was well known that she had at sometimes been on good terms with him. He used to visit her, always in the winter and usually very late at night. The shepherd, going up the hill, had heard her talking, and a man's voice, a very deep voice, answering her.

Under her bed there were rows of jam-jars, all empty and all clean. There was no money in the house, and no property of any value, and yet Old Allie had always been fat and well-liking; rich smells of food had come from her cottage, and she always seemed to have money to spend on beer or tobacco more to spend than she had coming in, the postmistress said.

No relatives came to her funeral. She was almost eighty when she died. I do not remember hearing how she first came to the village; certainly no family with her 
surname lived in the immediate neighbourhood. But to this day someone puts flowers on her grave, and nobody in the village admits to doing it, and no one is ever seen to place them there.

Old Allie was the last of the official witches. Old Lucy Blandamer had been more formidable. She was known to have stricken a woman with palsy, and caused another's arm to shrivel up. I saw the shrivelled arm and heard the story of it from the local doctor, who said that, of course, he did not believe in witchcraft, but he could not account for the state of that arm, nor could he cure it.

Lucy Blandamer had lost a finger herself, when a farmer's son shot and wounded a large, light-coloured hare in his father's orchard one night. The moon was shining, the hare shrieked in a woman's voice, and the young man saw a tall figure run through the orchard gate. $\mathrm{He}$ was too much frightened to pursue her, but the next day justified his fears. Lucy Blandamer was seen to have a bandage around her hand, and she set off, glumly enough, to the doctor's. Later it became known that she had lost a finger, but no one dared to ask her how this had happened....

Old Lucy Balndamer deeply hated her neighbours. In this she was different from Allie, who could be jovial and kind at times and who was particularly attentive to newborn babies. Whenever there was a birth in the village Allie turned up on the doorstep of the cottage, her large, usually inexpressive face creased into a smile. She was always taken upstairs immediately, and there she would stand, beside the cradle or the cot, looking intently at the babe. 
"What did she say?" I asked Mrs Rudkin, after I had passed Old Allie coming away from the cottage.

"She just looked at 'en and then she said, 'Thik 'un won't be too bad.' Wait till I tell Dad; he'll be proper pleased."

Whatever she said to or about the new child was remembered and believed in. Mrs Ridout told me, when Bobby Ridout had some form of nutritional disease which slowed his growth and made his bones illshaped, "Old Allie did say of he that he'd be a bad one to grow."

"How does she know, do you think?" I asked.

"There's never no telling wi" they." said Mrs Ridout. "Same as I do say, they know more then we give "em credit for. Poor old thing, too - "

Now, Old Allie was always fat and comfortable; her chimney showed a fine jet of smoke from early morning until late night, delicious smells of cooking came from her open door and she was respected and feared by everyone in the place. Old Lucy Blandamer, although she always looked thin and "miserable", they say, was certainly also respected and feared; and yet whenever either of the old women were spoken of, someone would be sure to add, "Poor old thing, too - " in almost a tone of condescension.

I think this was something like "whistling in the dark". Nothing about either of these two women was in the least pitiable, and, in any case, there was not much pity to spare in that village, but "poor old thing, too -" If you could say that about her, she could not be very formidable really. 
After Old Allie's death no one was qualified for her position; for a while village talk tried to invest Old Mother Goose-Step with the power and the terror, but although she was very ugly and had this nickname (because of the way she walked, shooting out her flat feet in front of her) she had too sharp a tongue, and it was not only sharp, it was "hung in the middle"; she talked too much. I heard some instances of her venom that would have convinced me of her powers, but no one would allow it. The hens that died, the little boy that had a fit just after she had sworn at him for chasing her cat, even the fact that she married the shepherd (being his fourth wife) when she was well over sixty -. The village talked of these things, but would not agree that they showed a supernatural power.

It had not struck me before that witches are, as it were, the Presidents of their villages, and rule by consent. However, it seems to be so, and Old Mother Goose-Step was never accepted, and her powers - if she had any - died with her. There is now not even a candidate for the position of Village Witch.

(Ackland, 1949a, pp.190-192)

Bessie Cornick is treated far more fancifully by Sylvia in 'Early One Morning', a story from The Salutation, (1932) where she too is called Rebecca.

Rebecca lives beyond the church in a cottage with "five great tufts of wormwood' (p.5) in the garden, in the shadow of the tower. Opposite, in the parsonage, lives the Revd Arthur Clay, who is 'young, lean, and anxious', (p.6) especially with his parishioners - both the quick and the dead. While passing Rebecca's cottage one morning, $\mathrm{Mr}$ Clay hears the voices of several of his flock coming from the hen-house 'with its door propped to with a frying-pan'. 
(p.7). They have been turned into fowls. Rebecca herself becomes a greyhound bitch 'milk-white, and young'. (p.9) The dog persuades Mr Clay to toll the bell - for old Rebecca who is dead. Such elegant witchcraft, it might be said, would have sorely tested the powers of Bessie Cornick.

So many witches, in one small village. Which leads me to wonder - was Warner herself among their number? While I was writing Chaldon Herring, several people advanced this theory with more or less conviction. Warner, I think, would probably have taken it as a compliment.

What is more, I was told by her gardener, Colin House, that, after her death, when he went to check on the gravestone, he found it propped upright. Underneath was a pair of crossed iron hinges, put there to stop the soul of a witch from leaving the earth. In 1978, in Chaldon, someone still believed in such practices.

\section{WORKS CITED}

ACKLAND, V. (Autumn, 1949) 'A Village Witch'. West Country Magazine, pp.190-192.

(Winter, 1949) 'Granny Moxon'. Countryman, pp.246-247.

WARNER, S. T. (1993 [1926]) Lolly Willowes, or The Loving Huntsman. London, Virago.

(2008 [1931]) Opus .7 in New Collected Poems. Ed. Claire Harman. Manchester, Carcanet.

(2000 [1932]) The Salutation. Horam, East Sussex, Tartarus Press.

Elegy for Grannie Moxon. Unpublished poem, undated TS, Dorset County Museum, Dorchester. WARNER, S.T. and ACKLAND, V. (1933) Whether $a$ Dove or a Seagull. New York. Viking Press. 